\section{The College - inside and out}

Sir: Having just read Matt Muijen's vivid interview in the Guardian (25 October 2006) in which he extolled the new-found virtues of the English mental health services from his viewpoint at the World Health Organization's Regional Office for Europe, I was prompted to make a similar inside/outside comment about the College from the perspective of the World Psychiatric Association (WPA). I, too, was immersed in the leadership of British psychiatry for almost 10 years, as Dean and President of the College, before being transported to an elected international post as Secretary General of the WPA.

What do I, and perhaps other voyeurs, see?

Interestingly, Matt Muijen overlooked an additional reason why what he called 'English psychiatry' has prospered in comparison with the discipline in many other European countries, and that is the crucial role of the College over the years as a strengthener of British psychiatrists.

This is perhaps easier to see from the outside than from the inside. The College is, for example, a sole national professional association that can speak directly to government, has retained an accountable, delegated mandate for standard setting and examining, exerts a scientific influence through four journals that resound throughout Europe and across the world, has over 150 paid staff and financial resources unparalleled elsewhere and, above all, has recently rediscovered an international collegiality.

The College is indeed therefore a massive resource for international psychiatry. But how to realise this potential fully on the world stage is a key question for the new College structures. How can it be one of the 'first among equals'? How can collaboration be facilitated? How should it use its resources (human and financial) to strengthen the WPA and its networks in low-income and isolated regions? How could it strengthen the ethical and educational roles of the WPA and support its disaster fund?

It is in the best interests of the College and the world community for these questions to be asked and answered. Going it alone is neither desirable nor practical.

The updated international programme planning for the annual meeting in Edinburgh is a real step forward, as is the greater participation of College members in sustaining the institutional vibrancy of the WPA.

Holding together national and international obligations, I can recall, is never easy. Yet it was right for the College at its annual meeting to celebrate the millennium with the world community in London and to celebrate the sociocultural diversity of mental health expertise.

Seeing the College inside out (and even at times upside down) is therefore a reason for optimism that other professional associations will become, over time, similarly empowered.

It is much to be hoped that this nettle will continue to be grasped by our College officers and that this new internationalism will flourish. This in turn will ensure that the WPA structures, which can at times creak and audibly groan, will increasingly become more fit for purpose. It is also, I believe, in the best long-term interests of the College.

\section{John Cox}

Honorary Fellow, Royal College of Psychiatrists; and Secretary General, World Psychiatric Association

\section{Natural disasters and their aftermath}

I am writing in response to the two papers
published about Sri Lanka in the July 2006 issue of International Psychiatry (vol. 3, no. 3, pp. 5-11). Danvers et al and Samarasinghe have contributed to our understanding of population responses to natural disasters; in the case of Sri Lanka, this was superimposed on a manmade disaster, in the form of 20 years of conflict. Any population exposed to either type of disaster, natural or manmade, may develop post-traumatic stress disorder in significant numbers. I am not surprised by the experience of Danvers et al of volunteers wanting to carry out psychosocial activities, including 'counselling', despite not having any psychosocial skills or training. But Sri Lankans have been treating trauma for millennia. My experience of working in Sri Lanka was that, at times, one did not need specific skills to deal with trauma-related problems, especially soon after the traumatic incident. I found that people wanted practical help or somebody to listen to their problems and experiences. I found that clergy had taken on the role of sympathetic/empathetic listeners and were doing an excellent job. Proper skills and training were, of course, needed for more complex problems, but these were not that common. However, the recent development of offers of counselling simply due to promotion of Western-style delivery of mental health services might not be appropriate.

I spent 1 year volunteering in northern Sri Lanka, from March 2005 to March 2006. I found it a wonderful and enriching experience, particularly as I am lucky enough to speak and understand Tamil reasonably fluently and understand basic Sinhalese. My work involved organising training in mental health problems following trauma, for example identification, referral pathways and basic counselling skills. The training sessions were given to staff working in relief and reconstruction (development work). Danvers et al worked in Jaffna, which incidentally had a history of good mental health services, with a team of experienced workers. However, in other north-eastern districts, such as Mullaitivu, Batticaloa and Trincomalee, this did not seem to be the case. Therefore, many affected people did not get the help that they might have benefited from. In my experience, raising awareness of mental health issues following trauma and providing information about what help is available and where, 